\title{
COMPARISON BETWEEN THE NUTRITIONAL QUALITY OF FLOUR OBTAINED FROM RAW, ROASTED AND FERMENTED SESAME (SESAMUM INDICUM L.) SEED GROWN IN NIGERIA
}

\author{
Folasade Maria Makinde ${ }^{1 凶}$, Rahman Akinoso ${ }^{2}$ \\ ${ }^{1}$ Department of Food Science and Technology, Bowen University, Osun State, Nigeria \\ ${ }^{2}$ Department of Food Technology, University of Ibadan, Ibadan, Nigeria
}

\begin{abstract}
Background. The most common form of utilization of sesame seed is its roasting, which supplies nutrients to the diet. Therefore, in view of the nutritional values of sesame seeds, the present study aimed at investigating the effect of roasting and fermentation on the nutritional quality of sesame flour.

Material and methods. Nigeria grown white sesame seeds (NCRI-98-60) were collected from National Cereal Research Institute (NCRI), Badegi, Nigeria. The seeds were divided into three portions, and treated as raw, roasted and fermented sesame seeds respectively. Each of the samples was milled, sieved and analysed for chemical composition using standard methods. Animal studies were used to evaluate the raw and processed sesame in terms of nutritional and histopathological qualities.

Results. The ranges of proximate contents from sesame were: protein 15.4-26.5 g/100 g, fat 52.4-62.8 g/100 g, crude fibre 3.34-3.89 g/100 g, ash 3.93-6.78 g/100 g, carbohydrate 11.7-13.4 g/100 g and energy value 550.7$-593.7 \mathrm{kcal} / \mathrm{g}$. Among the minerals, calcium was highest $(464-567 \mathrm{mg} / 100 \mathrm{~g})$ followed by phosphorus (442$-508 \mathrm{mg} / 100 \mathrm{~g}$ ), magnesium $(399-455 \mathrm{mg} / 100 \mathrm{~g}$ ) and potassium (336-489 mg/100 g). Total essential amino acid was within the range of $26.66-32.73 \mathrm{mg} / 100 \mathrm{~g}$ and these values were higher than FAO/WHO dietary requirement for infant and adult. Fatty acid profiles of raw, roasted and fermented sesame showed a predominance of oleic acid $(46.43 \%, 44.20 \%$, and $43.16 \%$, respectively) followed by linoleic acid $(36.76 \%, 39.02 \%$, and $39.67 \%$ ); while the least was behenic acid. The unsaturated/saturated fatty acid ratio ranges between 5.01-5.13. Phytate and oxalate concentrations of fermented sesame were significantly reduced than other food samples. In general, fermented sesame was found to have to have better nutritional quality as indicated by rat growth response. Correspondingly, the Food Efficiency Ratio (FER) value of 0.16 was higher than raw and roasted sesame respectively. Significantly higher Protein Efficiency Ratio (PER) value was also obtained for fermented sesame. The organ to body ratios of the test animals were influenced by treatments as recorded on heart, kidney, spleen, liver and pancreas.

Conclusion. The present study investigated the effect of roasting and fermentation on the nutritional quality of sesame flour. The findings showed that roasting and fermentation could enhance the nutritional quality of sesame seeds without detrimental effect on human.
\end{abstract}

Key words: sesame seeds, nutritional quality, roasting, fermentation, rat and organ weight 


\section{INTRODUCTION}

The search for lesser known and underutilized crops, many of which are potentially valuable as human food has been intensified to maintain a balance between population growth and agricultural product. In tropical developing countries where the supply of animal protein is inadequate to meet the rapid population growth, intense research efforts are currently directed toward identification and evaluation of underexploited oil seeds, which normally a have considerable high protein content. Such studies are of great importance to reduce hunger and malnutrition among the vulnerable group which basically consist of children and pregnant women. In the tropical regions of Africa, numerous varieties of oil crops occur ranging from commonly known and utilized ones such as groundnut, soybean, palm kernel, cotton seed, olive, melon seed, linseed and safflower to underutilized ones such as walnut, locust bean, African oil bean and sesame seed.

Sesame seed (Sesamum indicum L., synonymous with $S$. orientale L.), also known as sesamum, gingelly, sim sim, benniseed, and til is probably the most ancient oilseed crop. It is not clear where the seed originated, but it is speculated that it was native to tropical Africa. Moreover, the importance of sesame in the economies of several African countries justifies the African continent to be the centre of its origin. It has since travelled all over the world and is now extensively grown in many tropical and warm temperate regions [Biabani and Pakniyat 2008]. The genus Sesamum belongs to the family Pedaliaceae, which contains more than 30 species, of which only S. indicum L. is cultivated [Padma et al. 2011]. A large number of these occur in Africa (18 exclusively), 8 in the India-Sri Lanka region (5 exclusively), and others occurring in several regions on a non-exclusive basis [Weiss 2000]. The total world crop area under sesame is about 6 million hectares. Sixty-six percent of this is concentrated is Asia, twenty five percent of the world sesame is planted in Africa (mainly Nigeria, Ethiopia and Sudan) and 8\% in America, Venezuela, Mexico, Guatemala and Columbia) as reported by Federal Institute for Industrial Research [1990]. Nigeria is one of the major producers of sesame seed in Africa and it is found predominantly in Benue, Nasarawa and Jigawa States. Nigeria is the fifth largest producer of the commodity in the world with an estimated production of 120,000 metric tonnes annually [NCRI 2003]. The leading world producers are India, China, Mexico and Sudan in Africa. As a crop, capable of growing in areas where growth requirements are quite limited, sesame has a key role in sustaining food provision in disadvantaged areas of the tropical Africa. Total annual consumption is about $65 \%$ for oil extraction and $35 \%$ for food. The food segment includes about $42 \%$ roasted, $12 \%$ grounded, $36 \%$ washed and processed and $10 \%$ roasted and salted [RMRDC 2004]. In Africa, the most popular method of preparing this seed is cooking or roasting. Fermented sesame seeds (Ogirisaro) are popular in Sierra Leone but not very common in the other African countries. Limited studies have been conducted to explore the nutritional asset of sesame seed grown in tropical Africa. Raw sesame seeds have been shown to contain high levels of undesirable chemical compounds, majorly phytate and oxalate usually found in the seed hulls which lower the bioavailability of minerals and digestibility of plant proteins thereby limiting its use as food ingredient [Giami and Isichei 1999]. Consequently, sesame seed must be subjected to various processing conditions before it is consumed by humans.

Enhancement of the nutritional quality of sesame seeds can be anticipated through processing (such as roasting and fermentation) prior to consumption. The knowledge of how processing conditions affect nutrient availability is critical to develop structured foods to meet the nutritional needs of end users. No comprehensive study has been reported simultaneously to show chemical composition, nutritional and histopathological qualities of sesame seeds grown in African tropics as affected by roasting and fermentation. The purpose of the present study was to establish the nutritional qualities of raw and processed sesame seeds grown in Nigeria in view of their increased utilization in human diets.

\section{MATERIAL AND METHODS}

\section{Materials}

Nigeria grown white sesame seeds (NCRI-98-60) were collected from National Cereal Research Institute (NCRI), Badegi, Nigeria. The sample was transported to the laboratory in zip-lock polyethylene sample bags. 


\section{Processing of raw, roasted and fermented sesame seeds}

Raw. The whole seeds were soaked in water (1:5 $\mathrm{w} / \mathrm{v}$ ) ratio for $4 \mathrm{~h}$ at temperature of $29 \pm 2^{\circ} \mathrm{C}$, followed by dehulling with palms of hand and washed with water. The dehulled seeds were dried in an air oven (GallenKamp BS Oven 250) at $105^{\circ} \mathrm{C}$ for $12 \mathrm{~h}$, milled (Wiley mill, 30 mesh) to obtain raw sesame flour and stored in a glass container.

Roasting. Roasted sesame was prepared by placing raw seeds in Pyrex petri dish (8.0-diameter) and roasted at $160^{\circ} \mathrm{C}$ for $25 \mathrm{~min}$ using a household toaster oven (Hamilton Brands, Washington, USA). The temperature of the oven was calibrated using a thermocouple to detect actual temperature at the sample location. After roasting, the seeds were allowed to cool to ambient temperature, milled (Wiley mill, $30 \mathrm{mesh}$ ) to obtain roasted sesame flour and stored in a glass container.

Fermentation. Fermented sesame seeds were prepared by cooking $200 \mathrm{~g}$ dehulled sesame in boiling water for $6 \mathrm{~h}$ and cooled. The cooked seeds were placed in a plastic container with a tight lid and sealed. The samples were allowed to ferment at $35 \pm 2{ }^{\circ} \mathrm{C}$ for 7 days and oven dried at $105^{\circ} \mathrm{C}$ for $12 \mathrm{hr}$ to bring an end to fermentation, milled (Wiley mill, $30 \mathrm{mesh}$ ) to obtain fermented sesame flour and stored in a glass container.

\section{Nutritional composition}

Proximate analysis. Proximate analysis was carried out on the raw, roasted and fermented sesame flours. The moisture, crude protein $(\mathrm{N} \times 6.25)$, fat, ash and fibre were determined by standard procedures [AOAC 2005]. Total carbohydrates were calculated by difference. The energy value was estimated (kcal/g) following the method as described by Ekanayake et al. [1999]. All proximate analyses of the sesame flours were carried out in triplicate.

Mineral analysis. Potassium was determined using flame photometry (Corning, UK Model 405). Phosphorus was determined by the phosphovanadomolybdate (yellow) method [AOAC 2005]. The other elemental contents ( $\mathrm{Ca}, \mathrm{Mg}, \mathrm{Fe}, \mathrm{Se}, \mathrm{Zn}$ and $\mathrm{Mn}$ ) were determined, after wet digestion of sample ash with a mixture of concentrated nitric acid, sulphuric acid and perchloric acid (10:0.5:2, v/v) using Atomic
Absorption Spectrophotometer (AAS, Hitachi Z6100, Tokyo, Japan). All the determinations were carried out in triplicates and minerals reported in $\mathrm{mg} / 100 \mathrm{~g}$.

\section{Amino acid determination}

The amino acid profile was determined using the method described by Sparkman et al. [1958]. Each sample was initially dried to constant weight, defatted, hydrolyzed and evaporated. The amino acids of the samples were analysed by ion exchange chromatography (IEC) using the Technicon Sequential Multisample (TSM) Amino Acid Analyzer (Technicon Instruments Corporation, New York) which is designed to separate and analyse free acidic, neutral and basic amino acids of the hydrolysate. The period of analysis was $76 \mathrm{~min}$ for each sample. The gas flow rate was $0.50 \mathrm{~mL} \cdot \mathrm{min}^{-1}$ at $60^{\circ} \mathrm{C}$ with reproducibility consistent within $\pm 3 \%$. The net height of each peak produced by the chart recorder of the TSM (each representing an amino acid) was measured and calculated. Norleucine was the internal standard. The amino acid values reported were averages of two determinations. Tryptophan was not determined.

\section{Fatty acids determination}

Fatty acid compositions of the samples were analysed using gas-liquid chromatography (with omega wax capillary column Supelco, USA). The lipid classes were separated by thin layer chromatography on silica gel G 60 (Merck, Darmstadt), using n-hexane/ ethyl ether/acetic acid (73/25/2/v/v/v) as developing solvent. The fatty acids of phospholipids and triglycerides were transformed with sodium methylate into methyl esters.

\section{Anti-nutritional composition}

Determination of phytate. The phytate content was determined by the method described by Maga [1982]. Two grams of each finely ground sample was soaked in $20 \mathrm{~mL}$ of $0.2 \mathrm{~N} \mathrm{HCl}$ and filtered. After filtration, $0.5 \mathrm{~mL}$ of the filtrate was mixed with $1 \mathrm{~mL}$ ferric ammonium sulphate solution in a test tube, boiled for $30 \mathrm{~min}$ in a water bath, cooled in ice for $15 \mathrm{~min}$ and centrifuged at $3000 \mathrm{rpm}$ for $15 \mathrm{~min}$. One millilitre of the supernatant was mixed with $1.5 \mathrm{~mL}$ of 2,2-pyridine solution and the absorbance measured in a spectrophotometer at $519 \mathrm{~nm}$. The concentration of phytic 
acid was obtained by extrapolation from a standard curve using standard phytic acid solution.

Determination of oxalate. Oxalate was determined following the standard method [AOAC 2005]. $1 \mathrm{~g}$ of the sample was weighed into $100 \mathrm{~mL}$ conical flask. $75 \mathrm{~mL}$ of $3 \mathrm{M} \mathrm{H}_{2} \mathrm{SO}_{4}$ was added and the solution was carefully stirred intermittently with a magnetic stirrer for about $1 \mathrm{~h}$ and then filtered using Whatman No. 1 filter paper. The sample filtrate (extract; $25 \mathrm{~mL}$ ) was collected and titrated against hot $\left(80-90^{\circ} \mathrm{C}\right) 0.1 \mathrm{~N} \mathrm{KMnO}_{4}$ solution to the point when a faint pink colour appeared that persisted for at least $30 \mathrm{~s}$. The concentration of oxalate in each sample was obtained from the calculation:

$1 \mathrm{~mL} 0.1$ permanganate $=0.006303 \mathrm{~g}$ oxalate .

\section{Biological evaluation of protein quality}

Test animals. Twenty wistar albino rats (Rattus norvegicus), 4 weeks old, were obtained from the Animal Breeding Centre, Department of Veterinary Physiology and Pharmacology, Faculty of Veterinary Medicine, University of Ibadan, Nigeria. They were randomly divided into groups of five and acclimatized in polypropylene metabolic cages housed in a tem-

Table 1. Composition of basal diet, $\mathrm{g} / \mathrm{kg}$

\begin{tabular}{lc}
\hline \multicolumn{1}{c}{ Ingredient } & Quantity \\
\hline Fermented corn flour & 647.5 \\
Glucose & 50.0 \\
Sucrose & 150.0 \\
Non-nutritive cellulose & 50.0 \\
(microgranular cellulose) & \\
Vegetable oil & 100.0 \\
Vitamin mixture* & 20.0 \\
Oyster shell & 10.0 \\
Bone meal & 20.0 \\
Sodium chloride & 2.5 \\
\hline
\end{tabular}

*Vitamin mixture: vitamin A - $1000 \mathrm{IU}$, vitamin D - $100 \mathrm{IU}$ vitamin $\mathrm{E}-10 \mathrm{IU}$, vitamin $\mathrm{K}-0.5 \mathrm{mg}$, thiamine $-0.5 \mathrm{mg}$, riboflavin $-1 \mathrm{mg}$, pyrodoxine $-0.4 \mathrm{mg}$, pantothenic acid $-4 \mathrm{mg}$, niacin $-4 \mathrm{mg}$, choline $-200 \mathrm{mg}$, inositol $-25 \mathrm{mg}$, para-aminobenzoinc acid $-10 \mathrm{mg}$, vitamin $\mathrm{B}_{12}-2 \mathrm{mg}$, biotin $-0.02 \mathrm{mg}$, folic acid $-0.2 \mathrm{mg}$, added cellulose to make up to $1 \mathrm{~g}$. perature controlled room $\left(22 \pm 1^{\circ} \mathrm{C}\right)$ with $50 \%$ relative humidity and $12 \mathrm{~h}$ photoperiod. The control and experimental diets along with water were fed to respective animal groups ad libitum for 28 days.

Diet composition. The diet of rats consisted of casein (control), protein-free (basal diet), raw, roasted and fermented sesame flours (experimental diets). All the diets except for basal diet, consisted of $10 \%$ protein. Experimental and control diets were prepared by incorporating the processed sesame flours and casein respectively into the basal diet to achieve an iso-nitrogenous diet at $10 \%$ protein level. The group of rat fed with casein as an active source of protein served as control. The diets were prepared and stored in airtight glass containers a week prior to the experiment. The composition of the basal diets was as shown in Table 1 .

Growth performance assay. Weighed diet was given daily and unconsumed diet was collected and weighed to calculate the feed intake (FI) values. Weight of the rats was recorded twice in a week and the body weight gain (BWG) was calculated at the end of the experiment. The protein content of the diet was determined by micro-Kjeldahl method [AOAC 2005] and feed efficiency ratio (FER), protein efficiency ratio (PER), net protein retention (NPR), protein retention efficiency (PRE) and feed conversion ratio (FCR) were calculated according to the method of Chapman et al. [1959].

At the end of 28 days, one rat per replicate was selected from the five treatments and sacrificed. The heart, kidney, spleen, liver and pancreas were removed, weighed and the organ to body ratio was determined.

\section{Statistical analysis}

The data were analysed using SPSS/PC + version 15.0 statistical software. Statistical parameters were estimated with analysis of variance (ANOVA). Differences between means were evaluated by the Duncan multiple range test and significance was accepted at $p \leq 0.05$.

\section{RESULTS}

\section{Proximate and mineral composition of sesame flour}

The proximate compositions of raw, roasted and fermented sesame are given in Table 2. The protein content of sesame samples ranged between $26.5 \mathrm{~g} / 100 \mathrm{~g}$ 
Makinde F.M., Akinoso R., 2014. Comparison between the nutritional quality of flour obtained from raw, roasted and fermented sesame (Sesamum indicum L.) seed grown in Nigeria. Acta Sci. Pol., Technol. Aliment. 13(3), 309-319.

for raw sesame, $20.8 \mathrm{~g} / 100 \mathrm{~g}$ for roasted sesame and $15.4 \mathrm{~g} / 100 \mathrm{~g}$ for fermented sesame. The raw sesame was significantly higher in protein content when compared with the roasted and fermented sample respectively $(p \leq 0.05)$. The fat contents of both roasted $(55.4 \mathrm{~g} / 100 \mathrm{~g})$ and fermented $(62.8 \mathrm{~g} / 100 \mathrm{~g})$ sesame were higher than the raw sample $(52.37 \mathrm{~g} / 100 \mathrm{~g})$.

The ash content of fermented sesame $(6.78 \mathrm{~g} / 100 \mathrm{~g})$ was significantly higher than that of the roasted sesame $(6.05 \mathrm{~g} / 100 \mathrm{~g})$ and raw sesame $(3.93 \mathrm{~g} / 100 \mathrm{~g})$. A lower crude fibre was observed in the fermented sesame than the raw and roasted sesame respectively ( 3.34 vs. 3.86 ,
$3.89 \mathrm{~g} / 100 \mathrm{~g})$. The carbohydrate content of fermented sesame was $11.65 \mathrm{~g} / 100 \mathrm{~g}$ which was significantly lower than 13.37 and $13.92 \mathrm{~g} / 100 \mathrm{~g}$ for raw and roasted sesame respectively. However, the energy value of fermented sesame $(593.70 \mathrm{kcal} / \mathrm{g})$ was significantly higher than roasted sesame $(567.42 \mathrm{kcal} / \mathrm{g})$ and that of raw sample $(550.67 \mathrm{kcal} / \mathrm{g})$.

Calcium was the predominant mineral followed by phosphorus, magnesium and potassium while other elements were present in comparatively low concentrations as given in Table 3. The macro mineral elements were in a range of calcium $(464.97-567.91 \mathrm{mg} / 100 \mathrm{~g}$ ),

Table 2. Proximate composition of raw, roasted and fermented sesame on dry weight basis (mean \pm SD, $\mathrm{n}=3$ ), g/100 g

\begin{tabular}{lrrc}
\hline \multicolumn{1}{c}{ Component } & Raw sesame & Roasted sesame & Fermented sesame \\
\hline Crude protein & $26.47^{\mathrm{c}} \pm 0.01$ & $20.77^{\mathrm{b}} \pm 0.01$ & $15.40^{\mathrm{a}} \pm 0.01$ \\
Crude lipid & $52.37^{\mathrm{a}} \pm 0.02$ & $55.37^{\mathrm{b}} \pm 0.02$ & $62.84^{\mathrm{c}} \pm 0.04$ \\
Crude fibre & $3.86^{\mathrm{b}} \pm 0.01$ & $3.89^{\mathrm{b}} \pm 0.02$ & $3.34^{\mathrm{a}} \pm 0.03$ \\
Ash & $3.93^{\mathrm{a}} \pm 0.01$ & $6.05^{\mathrm{b}} \pm 0.02$ & $6.78^{\mathrm{c}} \pm 0.01$ \\
Carbohydrate & $13.37^{\mathrm{b}} \pm 0.02$ & $13.92^{\mathrm{c}} \pm 0.03$ & $11.65^{\mathrm{a}} \pm 0.01$ \\
Energy, kcal/g & $550.67^{\mathrm{a}} \pm 0.02$ & $567.42^{\mathrm{b}} \pm 0.02$ & $593.70^{\mathrm{c}} \pm 0.02$ \\
\hline
\end{tabular}

Figures across the columns with different letters are significantly different $(P \leq 0.05)$.

Table 3. Mineral composition of raw, roasted and fermented sesame on dry weight basis (mean $\pm \mathrm{SD}, \mathrm{n}=3$ ), $\mathrm{mg} / 100 \mathrm{~g}$

\begin{tabular}{lccc}
\hline \multicolumn{1}{c}{ Mineral } & Raw sesame & Roasted sesame & Fermented sesame \\
\hline Calcium & $464.97^{\mathrm{a}} \pm 0.68$ & $519.70^{\mathrm{b}} \pm 0.57$ & $567.91^{\mathrm{c}} \pm 0.43$ \\
Potassium & $336.75^{\mathrm{a}} \pm 0.79$ & $461.16^{\mathrm{b}} \pm 1.52$ & $489.43^{\mathrm{c}} \pm 0.57$ \\
Phosphorus & $442.94^{\mathrm{a}} \pm 0.58$ & $474.08^{\mathrm{b}} \pm 1.00$ & $508.50^{\mathrm{c}} \pm 0.54$ \\
Magnesium & $399.65^{\mathrm{a}} \pm 1.00$ & $429.43^{\mathrm{b}} \pm 0.93$ & $455.70^{\mathrm{c}} \pm 0.53$ \\
Iron & $6.42^{\mathrm{a}} \pm 0.02$ & $7.08^{\mathrm{b}} \pm 0.12$ & $8.00^{\mathrm{c}} \pm 0.05$ \\
Zinc & $7.97^{\mathrm{a}} \pm 0.13$ & $10.07^{\mathrm{b}} \pm 0.03$ & $10.39^{\mathrm{c}} \pm 0.06$ \\
Manganese & $1.50^{\mathrm{a}} \pm 0.06$ & $1.47^{\mathrm{a}} \pm 0.06$ & $5.00^{\mathrm{b}} \pm 1.00$ \\
Selenium & $0.02^{\mathrm{a}} \pm 0.01$ & $0.01^{\mathrm{a}} \pm 0.01$ & $0.07^{\mathrm{b}} \pm 0.01$ \\
Ca/P & $1.05^{\mathrm{a}}$ & $1.10^{\mathrm{b}}$ & $1.12^{\mathrm{b}}$ \\
Ca/Mg & $1.16^{\mathrm{a}}$ & $1.21^{\mathrm{b}}$ & $1.25^{\mathrm{b}}$ \\
\hline
\end{tabular}

Mean values with the same superscript in a column are not significantly different $(P \leq 0.05)$. $\mathrm{Ca} / \mathrm{P}$ - calcium to phosphorus ratio, $\mathrm{Ca} / \mathrm{Mg}$ - calcium to magnesium ratio. 
Makinde F.M., Akinoso R., 2014. Comparison between the nutritional quality of flour obtained from raw, roasted and fermented sesame (Sesamum indicum L.) seed grown in Nigeria. Acta Sci. Pol., Technol. Aliment. 13(3), 309-319.

phosphorus (442.94-508.50 $\mathrm{mg} / 100 \mathrm{~g})$, potassium (336.75-489.43 $\mathrm{mg} / 100 \mathrm{~g})$ and magnesium (399.65$-455.70 \mathrm{mg} / 100 \mathrm{~g})$ respectively. Fermented sesame had the highest concentration of the minerals which were significantly different from raw and roasted samples. Nutritionally, the ratio of $\mathrm{Ca} / \mathrm{P}$ of the flour samples range between 1.05 for raw sesame, 1.10 for roasted sesame and 1.12 for fermented sesame. $\mathrm{Ca} / \mathrm{Mg}$ ratio for raw, roasted and fermented sesame samples were $1.16,1.21$ and 1.25 respectively.

\section{Amino acid composition}

The amino acids compositions of raw and processed sesame are given in Table 4. The total essential amino acids composition of the raw, roasted and fermented sesame samples were 32.73, 28.89 and $26.66 \mathrm{mg} / 100 \mathrm{~g}$ respectively. The highest concentration of essential amino acids for the raw, roasted and fermented seeds was leucine, while the least concentration was lysine. Also, for the non-essential amino acids, the total concentration was $40.39 \mathrm{mg} / 100 \mathrm{~g}$

Table 4. Amino acid composition of raw, roasted and fermented sesame (mean $\pm \mathrm{SD}, \mathrm{n}=3$ ), $\mathrm{mg} / 100 \mathrm{~g}$ protein

\begin{tabular}{|c|c|c|c|c|c|}
\hline \multirow{2}{*}{ Amino acid } & \multirow{2}{*}{ Raw sesame } & \multirow{2}{*}{ Roasted sesame } & \multirow{2}{*}{ Fermented sesame } & \multicolumn{2}{|c|}{ EAA $^{*}$} \\
\hline & & & & infant & adult \\
\hline \multicolumn{6}{|c|}{ Essential amino acids } \\
\hline Valine & $4.97^{c} \pm 0.06$ & $4.56^{\mathrm{b}} \pm 0.06$ & $4.34^{\mathrm{a}} \pm 0.05$ & 3.50 & 1.30 \\
\hline Histidine & $3.83^{\mathrm{c}} \pm 0.08$ & $3.02^{\mathrm{b}} \pm 0.03$ & $2.27^{\mathrm{a}} \pm 0.10$ & 1.90 & 1.60 \\
\hline Lysine & $3.12^{\mathrm{c}} \pm 0.03$ & $2.85^{\mathrm{b}} \pm 0.06$ & $2.66^{\mathrm{a}} \pm 0.06$ & 5.80 & 1.60 \\
\hline Leucine & $7.89^{\mathrm{c}} \pm 0.06$ & $7.08^{\mathrm{b}} \pm 0.03$ & $6.21^{\mathrm{a}} \pm 0.03$ & 6.60 & 1.90 \\
\hline Isoleucine & $4.34^{\mathrm{c}} \pm 0.02$ & $3.95^{\mathrm{b}} \pm 0.06$ & $3.83^{\mathrm{a}} \pm 0.10$ & 2.80 & 1.30 \\
\hline Threonine & $5.16^{\mathrm{b}} \pm 0.06$ & $4.49^{\mathrm{a}} \pm 0.12$ & $4.57^{\mathrm{a}} \pm 0.10$ & 3.40 & 0.90 \\
\hline Methionine & $3.42^{\mathrm{c}} \pm 0.06$ & $2.94^{\mathrm{b}} \pm 0.04$ & $2.78^{\mathrm{a}} \pm 0.03$ & 2.50 & 1.70 \\
\hline Tryptophan & ND & ND & ND & & \\
\hline Total & 32.73 & 28.89 & 26.66 & & \\
\hline \multicolumn{6}{|c|}{ Non-essential amino acids } \\
\hline Glycine & $3.47^{\mathrm{c}} \pm 0.06$ & $3.22^{\mathrm{b}} \pm 0.02$ & $2.94^{\mathrm{a}} \pm 0.03$ & & \\
\hline Alanine & $3.46^{\mathrm{b}} \pm 0.04$ & $3.39^{\mathrm{a}} \pm 0.03$ & $3.43^{b} \pm 0.03$ & & \\
\hline Serine & $3.03^{\mathrm{c}} \pm 0.03$ & $2.86^{\mathrm{b}} \pm 0.01$ & $2.57^{\mathrm{a}} \pm 0.02$ & & \\
\hline Aspartic acid & $9.02^{\mathrm{c}} \pm 0.02$ & $8.34^{b} \pm 0.03$ & $7.86^{a} \pm 0.02$ & & \\
\hline Glutamic acid & $17.03^{b} \pm 0.03$ & $16.91^{\mathrm{b}} \pm 0.06$ & $15.29^{\mathrm{a}} \pm 0.28$ & & \\
\hline Phenylalanine & $4.38^{b} \pm 0.03$ & $4.27^{b} \pm 0.02$ & $4.11^{\mathrm{a}} \pm 0.10$ & & \\
\hline Total & 40.39 & 38.99 & 36.20 & & \\
\hline
\end{tabular}

Mean values with the same superscript in a column are not significantly different $(P \leq 0.05)$.

*Suggested profile of essential amino acid requirement for infant and adult FAO/WHO [21]. 
Makinde F.M., Akinoso R., 2014. Comparison between the nutritional quality of flour obtained from raw, roasted and fermented sesame (Sesamum indicum L.) seed grown in Nigeria. Acta Sci. Pol., Technol. Aliment. 13(3), 309-319.

for raw sesame, $38.99 \mathrm{mg} / 100 \mathrm{~g}$ for roasted sesame and $36.20 \mathrm{mg} / 100 \mathrm{~g}$ for the fermented sesame. Glutamic acid was the highest concentration of non-essential amino acid while serine was the least.

\section{Fatty acid composition}

The most abundant fatty acids in raw, roasted and fermented sesame samples were oleic acid
(46.43, 44.20, and $43.16 \%$ respectively), linoleic acid $(36.76 \%, 39.02 \%$, and $39.67 \%$ respectively), palmitic acid $(8.42 \%, 8.69 \%$, and $8.84 \%$ respectively), and stearic acid $(6.99 \%, 6.67 \%$, and $7.21 \%$ respectively) as given in Table 5 . There were variations in fatty acid composition as regards raw, roasted and fermented sesame. For the saturated fatty acids (SFA), palmitic acid was the most dominant fatty acids, while behenic

Table 5. Fatty acid composition of raw, roasted and fermented sesame (mean $\pm \mathrm{SD}, \mathrm{n}=3$ ), $\%$

\begin{tabular}{|c|c|c|c|}
\hline Fatty acid & Raw sesame & Roasted sesame & Fermented sesame \\
\hline Lauric acid (C12:0) & 0.06 & 0.07 & 0.08 \\
\hline Palmitic acid (C16:0) & 8.42 & 8.69 & 8.84 \\
\hline Palmitoleic acid (C16:1) & 0.11 & 0.17 & 0.19 \\
\hline Stearic acid (C18:0) & 6.99 & 6.67 & 7.21 \\
\hline Oleic acid (C18:1) & 46.43 & 44.20 & 43.16 \\
\hline Linoleic acid (C18:2) & 36.76 & 39.02 & 39.67 \\
\hline Linolenic acid (C18:3) & 0.32 & 0.30 & 0.35 \\
\hline Capric acid & 0.12 & 0.15 & 0.19 \\
\hline Arachidic acid (C20:0) & 0.93 & 0.90 & 0.92 \\
\hline Behenic acid (C22:0) & 0.05 & 0.06 & 0.06 \\
\hline \multicolumn{4}{|l|}{ Saturated fatty acids } \\
\hline Palmitic acid & 8.42 & 8.69 & 8.34 \\
\hline Stearic acid & 6.99 & 6.67 & 7.31 \\
\hline Arachidic acid & 0.93 & 0.90 & 0.92 \\
\hline Behenic acid & 0.05 & 0.06 & 0.06 \\
\hline Total & 16.39 & 16.32 & 16.63 \\
\hline \multicolumn{4}{|c|}{ Monounsaturated fatty acids } \\
\hline Oleic acid & 46.43 & 44.20 & 43.16 \\
\hline Palmitoleic acid & 0.11 & 0.17 & 0.19 \\
\hline Total & 46.54 & 44.37 & 43.35 \\
\hline \multicolumn{4}{|c|}{ Polyunsaturated fatty acids } \\
\hline Linoleic acid & 36.76 & 39.02 & 39.67 \\
\hline Linolenic acid & 0.32 & 0.30 & 0.35 \\
\hline Total & 37.08 & 39.32 & 40.02 \\
\hline $\mathrm{U} / \mathrm{S}$ ratio & 5.10 & 5.13 & 5.01 \\
\hline
\end{tabular}


Table 6. Some antinutritional components of raw, roasted and fermented sesame on dry weight basis (mean $\pm \mathrm{SD}, \mathrm{n}=3$ ), $\mathrm{mg} / 100 \mathrm{~g}$

\begin{tabular}{lccc}
\hline \multicolumn{1}{c}{ Component } & Raw sesame & Roasted sesame & Fermented sesame \\
\hline Phytate & $30.00^{\mathrm{c}} \pm 1.00$ & $18.33^{\mathrm{b}} \pm 0.18$ & $10.33^{\mathrm{a}} \pm 0.50$ \\
Oxalate & $85.67^{\mathrm{c}} \pm 0.23$ & $36.00^{\mathrm{b}} \pm 1.00$ & $24.95^{\mathrm{a}} \pm 0.18$ \\
\hline
\end{tabular}

Mean values with the same superscript in a column are not significantly different $(P \leq 0.05)$.

acid was the least. The total saturated fatty acid of fermented sample $(16.63 \%)$ was the highest when compared with raw sample $(16.39 \%)$ and roasted sample $(16.32 \%)$. The ratio of unsaturated fatty acids to saturated fatty acids (U/S ratio) ranged between 5.10 for raw sesame, 5.13 for roasted sesame and 5.01 for fermented sesame.

\section{Antinutritional composition}

The antinutritional compositions of sesame are given in Table 6 . The phytate concentration ranged between $30.00 \mathrm{mg} / 100 \mathrm{~g}$ for raw sesame, $18.33 \mathrm{mg} / 100 \mathrm{~g}$ for roasted sesame and $10.3 \mathrm{mg} / 100 \mathrm{~g}$ fermented sesame sample. Oxalate concentration ranged between $85.67 \mathrm{mg} / 100 \mathrm{~g}$ for raw sesame, $36.00 \mathrm{mg} / 100 \mathrm{~g}$ for roasted sesame and $24.95 \mathrm{mg} / 100 \mathrm{~g}$ fermented sesame sample.

\section{Nutritional quality of sesame flour}

The nutritional and histopathological characteristics of test animals fed with diets containing raw and processed sesame are given in Table 7. Food intake of fermented sesame was significantly higher than the roasted and raw samples (260.13 vs. $254.25 \mathrm{~g}$, $232.20 \mathrm{~g}$ ). The average weight gain of rats fed raw, roasted and fermented samples were $14.90 \mathrm{~g}, 23.00 \mathrm{~g}$ and $42.58 \mathrm{~g}$ respectively compared to casein diet 85.00 g. The raw sesame exhibits poor FER (0.06) value when compared to control and processed sesame. For roasted and fermented sesame included diets, higher FER values were recorded over raw sample. Correspondingly, the protein efficiency ratio (PER) value were 0.90 and 1.62 for roasted and fermented sesame containing diet fed rats, respectively, however, these values were lower compared to that of the casein control diet -2.64 . The net protein retention (NPR) of the fermented sesame was significantly higher than that of roasted and raw samples (2.17 vs. $1.47,1.44)$. The PRE of fermented sesame was significantly higher than of raw and roasted samples respectively ( 34.72 vs. $23.04,23.52)$. The values of feed conversion ratio (FCR) were 15.58, 11.05 and 6.16 for the raw, roasted and fermented sesame sample respectively.

The organ to body ratios of the test animals as given in Table 7 showed significant heavy weight on the experimental diets containing roasted and fermented sesame and the control while the organ weight on the diet with raw sesame were relatively low in weight $(p \leq 0.05)$.

\section{DISCUSSION}

The decrease in protein content as a result of fermentation is the direct result of leaching of some protein into the processing water especially during cooking prior to fermentation. Furthermore, this is an indication of increased protein catabolism by the activities of micro organisms responsible for fermentation. Similarly, the roasting process accelerates the Maillard reactions and subsequently making the protein and its amino acids significantly unavailable for digestion. The reactive carbonyl group of the sugar reacts with the nucleophilic amino group of the amino acid, and forms a complex mixture of molecules responsible for a range of flavours. The fermentation process also resulted in lipid enhancement as some micro organisms have the potential of producing oil during growth on substrate [Akindumila and Glatz 1998]. Thermal treatment of nuts in roasting process leads to changes in active substances in relation to the degree of heat treatment during preparation, which explains the significant increase in fat content of roasted sesame compared to that of raw sesame. Crude fat 
Makinde F.M., Akinoso R., 2014. Comparison between the nutritional quality of flour obtained from raw, roasted and fermented sesame (Sesamum indicum L.) seed grown in Nigeria. Acta Sci. Pol., Technol. Aliment. 13(3), 309-319.

Table 7. Nutritional characteristics of test animals fed diets of raw, roasted and fermented sesame

\begin{tabular}{lcccc}
\hline \multicolumn{1}{c}{ Characteristics } & Casein $($ control) & Raw sesame & Roasted sesame & Fermented sesame \\
\hline Feed intake, g & $346.63^{\mathrm{d}} \pm 0.58$ & $232.20^{\mathrm{a}} \pm 0.25$ & $254.25^{\mathrm{b}} \pm 0.29$ & $260.10^{\mathrm{c}} \pm 0.25$ \\
Protein intake, g & $34.66^{\mathrm{c}} \pm 0.50$ & $20.13^{\mathrm{a}} \pm 0.64$ & $25.43^{\mathrm{b}} \pm 0.50$ & $26.01^{\mathrm{b}} \pm 0.04$ \\
Mean weight gain, g & $85.00^{\mathrm{d}} \pm 1.00$ & $14.90^{\mathrm{a}} \pm 0.76$ & $23.00^{\mathrm{b}} \pm 0.29$ & $42.58^{\mathrm{c}} \pm 0.50$ \\
Weight loss, g & $14.25^{\mathrm{a}} \pm 0.05$ & $14.25^{\mathrm{a}} \pm 0.05$ & $14.25^{\mathrm{a}} \pm 0.05$ & $14.25^{\mathrm{a}} \pm 0.05$ \\
Protein consume, g & $4.66^{\mathrm{d}} \pm 0.06$ & $20.13^{\mathrm{a}} \pm 0.04$ & $25.43^{\mathrm{b}} \pm 0.50$ & $26.01^{\mathrm{c}} \pm 0.29$ \\
Feed efficiency ratio & $0.24^{\mathrm{d}} \pm 0.01$ & $0.06^{\mathrm{a}} \pm 0.03$ & $0.09^{\mathrm{b}} \pm 0.01$ & $0.16^{\mathrm{c}} \pm 0.02$ \\
Protein efficiency ratio & $2.45^{\mathrm{d}} \pm 0.06$ & $0.60^{\mathrm{a}} \pm 0.04$ & $0.90^{\mathrm{b}} \pm 0.01$ & $1.62^{\mathrm{c}} \pm 0.03$ \\
Net protein retention & $2.86^{\mathrm{c}} \pm 0.06$ & $1.44^{\mathrm{a}} \pm 0.11$ & $1.47^{\mathrm{a}} \pm 0.08$ & $2.17^{\mathrm{b}} \pm 0.08$ \\
Protein retention & $45.76^{\mathrm{d}} \pm 0.58$ & $23.04^{\mathrm{a}} \pm 0.66$ & $32.52^{\mathrm{b}} \pm 0.57$ & $34.72^{\mathrm{c}} \pm 0.76$ \\
Efficiency & & & & $6.16^{\mathrm{b}} \pm 0.25$ \\
Food conversion ratio & $4.08^{\mathrm{a}} \pm 0.11$ & $15.58^{\mathrm{d}} \pm 0.76$ & $11.05^{\mathrm{c}} \pm 0.10$ & \\
Organ: body weight ratio & & & & 3.86 \\
Lungs $\left(\times 10^{-3}\right)$ & 4.56 & 3.04 & 3.42 & 5.15 \\
Spleen $\left(\times 10^{-3}\right)$ & 5.37 & 3.95 & 4.38 & 6.28 \\
Kidney $\left(\times 10^{-3}\right)$ & 6.46 & 5.42 & 5.92 & 39.40 \\
Liver $\left(\times 10^{-3)}\right.$ & 41.00 & 34.08 & 38.60 & 3.64 \\
Pancreas $\left(\times 10^{-3}\right)$ & 4.09 & 3.03 & & 3.89 \\
\end{tabular}

content of raw and processed sesame were over twice the content of soybean (22.8-23.5\%) but comparable with pumpkin (47.0-49.2\%) and groundnut (48-49\%) grown in Nigeria [Salunkhe et al. 1985, Asiegbu 1989, Adeyeye 2010]. The significant increase in ash content observed in fermented sesame resulted from metabolic activities of microorganisms during fermentation. The process of roasting also resulted in decrease in moisture content that gave rise to increase in ash content. The observed decrease in fiber content of fermented sesame is perhaps due to extended cooking time to soften the seeds which resulted in the degradation and solubilisation of complex polysaccharides within the fibre matrix. Lower accessibility of micro organisms to insoluble fibre fraction during the fermentation may also contribute to observe decrease in fibre content. However, the crude fibre content of roasted sesame was significantly higher than that of fermented sesame and this could be attributed to heat applied. The depletion of carbohydrate during fermentation is an indication that they were used as source of energy by the fermenting micro organisms. Contrary, the roasted sesame recorded higher carbohydrate content than fermented sesame that suggested that roasting causes sesame granules to break down, softens the cellulose, and makes the starch more available. The increase in energy value observed with fermentation and roasting could be attributed to increase in fat content of the samples as fat contains about twice the food energy values of protein and carbohydrate.

Fermentation resulted in significant increase in mineral concentrations which is an indication of the conversion of the insoluble reserve foods by enzymes during fermentation. Also, observed decrease in phytate was responsible for the increase in mineral extractability as the major elements such as phosphorus, calcium and potassium are parts of the molecular structure of phytic acid and phytin [Duhan et al. 2002]. Similarly, the roasting process increases the digestibility of oilseed that initiated the release and increment in some minerals. The ratio of $\mathrm{Ca} / \mathrm{P}$ indicated that raw, roasted and fermented sesame were good sources of 
these essential mineral elements as food products containing $\mathrm{Ca} / \mathrm{P}$ ratio of greater than 1.0 is rated good, while less than 0.5 is rated poor [Nieman et al. 1992]. However, the $\mathrm{Ca} / \mathrm{Mg}$ ratios are low compared with the recommended value of 2.2 for maximum nutritional benefits [Recommended... 1989].

In general, fermented sesame had the lowest concentrations of amino acids than any of counterparts. This is by virtue of degradation of these amino acids by the fermenting micro organisms and high loss of nitrogen during the process. Similarly, the observed decrease in the roasted sesame compared to raw sesame is an indication of Maillard reactions that occurred during roasting process. It has been observed that little damage occurred during Maillard reactions unless the heat treatment causes the reaction to go beyond the deoxy-ketosyl stage which is often accompanied by severe destruction of lysine and arginine and, to a lesser extent, tryptophan, cystine and histidine [Muller and Tobin 1980]. However, by comparing the essential amino acid profile with the FAO/WHO [1990] reference standard, it was observed that the values of raw and processed sesame were higher than recommended values for infant and adult with the exception of lysine.

The raw sesame was high in monounsaturated fatty acid and polyunsaturated fatty acid composition as well as roasted and fermented samples. It is evident that essential fatty acid such as oleic and linoleic acid are primarily used to produce hormone like substance that regulates a wide range of functions, blood pressure, blood clotting, blood lipid-level and inflammation response to injury infections [Zwarts et al. 1999]; hence the consumption of sesame seed would serve as a good source. The U/S ratio is a clear indication of high amount of unsaturated fatty acid and can be positively considered from the nutritional point of view. In addition, the $\mathrm{U} / \mathrm{S}$ ratio could be regarded as useful criterium to measure edible oil quality; however, these ratios were higher than value of 3.40 reported for soybean grown in Nigeria [Ezeagu et al. 1998].

The phytate and oxalate concentrations of roasted and fermented sesame samples were lower when compared with raw sample. However, fermented sample had the lowest concentrations. This is due to the fact that initial soaking, hydration and cooking of the dehulled seeds had caused leaching of the some of these antinutrients into the processing water before the actual fermentation process. This is also attributed to diminishing effect of enzymes (phytase and polyphenol oxidase) produced by microorganisms during fermentation on these antinutrients. The only factor that could account for the lower concentrations of phytate and oxalate in roasted sesame was the heat applied as these antinutrients are thermo labile in nature.

The lower FI in rats fed with raw sesame than control and processed sesame were probably due to the difference between the diets in protein quality and effects of antinutritional compounds. The reduction in the levels of various anti nutritional substances by roasting and fermentation might be related to larger FI values compared to raw sesame. The raw sesame exhibits poor FER value when compared to control and processed sesame since the food and protein intake were low. The lower PER value of roasted and fermented sesame compared to casein may be attributed to loss of available lysine due to processing. Similarly, much of the methionine supplied in the diets could have been used to synthesise pancreatic enzymes. In the present study, the fermented sesame had intermediate protein quality in that the PER value fell within the range of 1.5-2.0 compared to casein with good protein quality -2.46 while raw and roasted samples had poor protein quality as described by Friedman [1996].

Organ to body weight is an important index of physiological and pathological status in man and animals. The findings suggest that the rats fed untreated (raw sesame) could not effectively utilize the nutrients in the diet compared to rats fed roasted and fermented sesame respectively. The high concentrations of phytate and oxalate initially observed in the raw sesame hinder the absorption of nutrients which subsequently affected the organ weight.

\section{CONCLUSION}

Roasted and fermented sesame seeds contain high protein, fat and energy values with nutritionally valuable minerals comparable with known protein-rich plant foods, such as groundnut and soybean. Processing also enhanced the amino acid and fatty acid profile of sesame. Considering the biological value, fermented sesame exhibited better rat growth response and protein quality compared to roasted sesame. The application of such potential processing methods will 
contribute to increased production and utilization of the crop for enhanced food and nutrition security in Nigeria and other developing African countries.

\section{ACKNOWLEDGEMENT}

Authors are grateful to the management and administrative authorities of Bowen University for their support.

\section{REFERENCES}

Adeyeye E.I., 2010. Effect of cooking and roasting on the amino acid composition of raw groundnut (Arachis hypogaea) seed. Acta Sci. Pol., Technol. Aliment. 9 (2), 201-216.

Akindumila F., Glatz B.A., 1998. Growth and oil production of Apiotrichum curvatum in tomato juice. J. Food Prot. 61 (11), 1515-1517.

AOAC, 2005. Official methods of analysis. Association of Official Analytical Chemists Washington, DC.

Asiegbu J.E., 1989. Some biochemical evaluation of fluted pumpkin seed. J. Sci. Food Agric. 40, 150-155.

Biabani A.R., Pakniyat H., 2008. Evaluation of seed yield-related characters in sesame (Sesamum indicum L.) using factor and path analysis. Pak. J. Biol. Sci. 11, $1157-1160$

Chapman D.G., Castillo R., Campbell J.A., 1959. Evaluation of proteins in foods. Canad. J. Biochem. Biophys. 37, 679-683.

Duhan A., Khetarpaul N., Bishnoi S., 2002. Content of phytic acid and $\mathrm{HCl}$-extractability of calcium, phosphorus and iron as affected by various domestic processing and cooking methods. Food Chem. 78, 9-14.

Ekanayake S., Jansz E.R., Nair B.M., 1999. Proximate composition, mineral and amino acid content of mature $\mathrm{Ca}$ navalia gladiata seeds. Food Chem. 66, 115-119.

Ezeagu I.E., Petzke K.J., Lange E., Metgea C.C., 1998. Fat content and fatty acid composition of oils extracted from selected wild gathered tropical plant seeds from Nigeria. JAOCS 75, 1031-1035.
FAO/WHO, 1990. Protein quality evaluation: Report of a Joint FAO/WHO Expert Consultation. FAO Rome.

Federal Institute for Industrial Research. 1990. (FIIR) Report on survey of selected agricultural raw material in Nigeria. Raw Materials Research and Development Council.

Friedman M., 1996. Nutritional value of proteins from different food sources. A review. J. Agric. Food Chem. 44, 6-29.

Giami S.Y., Isichei I., 1999. Preparation and properties of flours and protein concentrates from raw, fermented and germinated fluted pumpkin (Telfairia occidentalis Hook) seeds. Plant Foods Hum. Nutr. 54, 67-77.

Maga J.A., 1982. Phytates: Its chemistry, occurrence, food interactions. Nutritional significance and method of analysis. J. Agric. Food Chem. 30 (1), 1-7.

Muller H.G., Tobin G., 1980. Nutrition and food processing. CroomHelm London.

NCRI, 2003. Oil seeds research divisional report. National Cereal Research Institute. Annual Review Meeting. June, 10-13.

Nieman D.C., Butterworth D.E., Nieman C.N., 1992. Nutrition. WmC. Brown, Dbugye, USA, 237-312.

Padma N., Ramasamy P., Sujatha M., Umesh K.R., 2011. Wild crop relatives: Genomic and breeding resources. DOI: 10.1007/978-3-642-14871-2-16, 261-273.

Recommended Dietary Allowances. 1989. National Research Council. National Academic Press Washington D.C.

RMRDC, 2004. Survey report of ten selected agro raw materials in Nigeria. Raw Materials Research and Development Council. BENISEED (Maiden Edition).

Salunkhe D.K., Kadam S.S., Chavan J.K., 1985. Post-harvest biotechnology of food legumes. CRC Boca Raton, 132-140.

Sparkman D.H., Stein E.H., Moore L., 1958. Automatic recording apparatus for use in chromatography of amino acids. Anal. Chem. 30, 11-91.

Weiss E.A., 2000. Oilseed crops. Blackwell Sci. Oxford.

Zwarts L., Savage G.P., McNeil D.L., 1999. Fatty acid content of New Zealand grown walnuts (Juglans regia L.). Int. J. Food Sci. Nutr. 50, 189-194.

Accepted for print - Zaakceptowano do druku: 14.04.2014 